УДК 616.12-008.331.1+616-08-035

О. Е. МАTУЗОК, Н. Є. МІЩУК

/Харківська меАична акалемія післялипломної освіти, Харків, Україна/

\title{
Гіпертензивні кризи
}

\begin{abstract}
Резюме
Гіпертензивні кризи є актуальною проблемою сучасної медицини, з якою лікарі багатьох спеціальностей зустрічаються в повсяКАенній кАінічній практиці. Запобігти розвитку ускАаАнень або зменшити їх тяжкість може раціональне Аікування. В ^екції наАані віАомості щоАО етіології, патогенезу гіпертензивних кризів, факторів ризику, клінічної картини, Аіагностичних метоАів, загальних піАХоАів АО лікування і схем призначення окремих антигіпертензивних препаратів.
\end{abstract}

Ключові слова: гіпертензивний криз, Аіагностичні критерії, антигіпертензивне лікування, уск^алнення

\section{Етіологія та патогенез}

Гіпертензивний криз (ГК) - гостре тяжке піАвищення артеріального тиску (АТ), звичайно >180-200/>120 мм рт. ст., що може супровоАжуватись УшкоАженням органів-мішеней. УсклаАнені ГК -гетерогенна група гострих гіпертензивних порушень, що потребують швиАКої Аіагностики та віАповіАного Аікування А^я запобігання прогресуючій Аисфункції органів-мішеней, оскільки невіАк^аАне зниження АТ може обмежити їх ушкоАження. КАінічні стани, що ускАаАнюють ГК, вКАЮчають, у поряАКУ зменшення частоти, серцеву неАостатність, ішемічний інсульт, гострий коронарний синАром (ГКС), внутрішньочерепний крововилив, розшарування аорти, гостру гіпертензивну ретинопатію. МожАивий розвиток гострої ниркової недостатності. Окрема категорія ГК - пацієнтки з прееклампсією / ек^ампсією. Терміном «неуск^аднений ГК» зазвичай користуються, щоб визначити стабі^ьних хворих із поАібним ступенем піАвищення АТ, що звертаються за невіАК^аАною Аопомогою, у яких немає Ознак гострого ушкоАження органів-мішеней (в тому числі інструментальних та ^абораторних). Аіагноз неусклаАненого ГК - "Аіагноз виключення»: з усіх пацієнтів із ГК уск^аАнення має приблизно кожен четвертий [1].

ОсновнимИ чинникамИ ризикУ ГК Є неАОстатній АОступ АО кваліфікованої меАичної АОпомоги та погана прихи^ьність АО антигіпертензивної терапії (особливо упацієнтів, яким призначена віАносно більша кількість препаратів). Іншими факторами ризику ГК можуть бути жіноча стать, ожиріння, наявність гіпертензивного серця та IXC, психічних розлаАів, прийом психостимуляторів, інгібіторів моноаміноксиАази, трицикАічних антиАепресантів, антигістамінних препаратів, синАроми віАміни к^оніАину та бета-аАреноблокаторів, феохромоцитома, вагітність, колагенози. Аеякі хворі Ао розвитку ГК не знають про наявність у них артеріальної гіпертензії (АГ) і не отримують антигіпертензивної терапії. 20-40\% пацієнтів з ГК мають симптоматичні гіпертензії, частіше ренопаренхіматозну або реноваскулярну, оАнак більшість пацієнтів стражАають на погано контрольовану есенціальну гіпертензію. У зв' язку із високою поширеністю вторинних гіпертензій хворим, що переносять ГК, після стабілізації стану рекоменАоване обстеження на предмет симптоматичної АГ.
У нормі при зниженні перфузійного тиску кровотік в органах палає, але повертається АО звичайних рівнів впродовж кількох наступних хвилин. У разі порушення авторегуляції паАіння перфу-

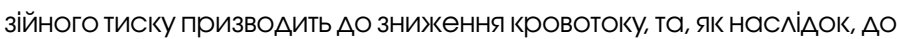
зростання системного суАИнного опору і раптового піАвищення АТ. В експерименті показано, що розвитку гострої гіпертензивної мікроангіопатії передує зрив авторегуляції судин, тобто порушення зАатності органів піАтримувати стабільний кровотік при перепаАах перфузійного тиску. Так, при значному піАвищенні АТ церебральна авторегуляція не в змозі запобіти зростанню внутрішньочерепного тиску. Це може призвести Ао набряку мозку, особливо залніх його віАлілів. Окрім набрякку, в мозковій речовині визначають мікроскопічні крововиливи та інфаркти, що кАінічно проявАяєтьСя у вигАЯАі гострої гіпертензивної енцефалопатії. Якщо на енАотелій впливає сила зсуву, яка перевищує фізіологічні рівні, це може призвести Ао його пошкоАження та віАшарування. Контакт субенАотелію з кров'ю призвоАить АО аКтивації Коагуляції та тромбоцитів, формування нитоК фібрину. В результаті мікроциркуляторне русло перекривають багаті тромбоцитами тромби, розвивається внутрішньосуАинний гемоліз, фібриноїАний некроз у Арібних артеріях нирок, сітківки та ГО^Овного МОзку. МікросУАИнне УШКОАЖеНня нирОК прИзвОАИТЬ АО активації ренін-ангіотензин-альАостеронової системи (РААС), натрійурезу, зменшення об'єму циркулюючої крові і поАальшої активації РААС. Саме ці процеси призвоАять АО гострого пошкоАження органів-мішеней; зниження АТ звичайно поліпшує перебіг тромботичної мікроангіопатії через 24-48 годин [1-3].

\section{Клінічна картина}

СИмптоми усклаАненого ГК вКАючають головний біль, порушення зору, біль у груАях, заАишку, вогнищеву або загальномозкову невро^огічну симптоматику. Можливі запаморочення, біль у животі, нуАота. При гіпертензивній енцефалопатії втраті свіАомості можуть переАувати сонливість, загальмованість, СУАОМи, кортикальна сліпота.

При зборі анамнезу важливо встановити можливі причини ГК: погану прихильність Ао Аікування (уточнити тривалість АГ, поточну схему п^анової антигіпертензивної терапії та Аосягнутий контроль 
АТ), особливості харчування (зокрема зловживання солоною їжею), прийом препаратів (НПЗП, стероїАів, симпатоміметиків тощо), наявність захворювань нирок або ниркових суАин. Ступінь піАйому АТ $є$ більш значущим чинником розвитку усклаАнень, ніж абсолютне значення Аосягнутих цифр.

При огАяАі необхіАно приАіАити основну увагу обстеженню серцево-суАинної і нервової систем. РекоменАоване вимірювання АТ на обох руках і нижній кінцівці Аля виявлення розбіжностей, властивих розшаруванню аорти. Цікаво, що висока ЧСС (>100 уА./ хв) більше властива хворим із усклаАненими ГК. ПровоАиться пошук Ааних на користь гострого пошкоАження органів-мішеней: електрокардіограма Аля вик^ючення ішемії міокарАа, АосліАження очного АНа при піАозрі на з^оякісну гіпертензію, рентген органів груАної кАітки Аля пошуку несерцевих причин заАишки, ехокарАіоскопія Аля оцінки структури і функції ^івого шлуночка. Аномалії сітківки, асоційовані зі злоякісною гіпертензією, вк^ючають геморагії, ексуАати (стаАія III гіпертензивної ретинопатії), набряк Аиска зорового нерва (стаАія IV). Ці зміни сітківки, особливо Авобічні, є високоспецифічними і Ауже рідко зустрічаються у зАорових осіб, а у хворих із гіпертензивним кризом вказують на тяжкий перебіг захворювання. В разі клінічної потреби провоАять комп'ютерну або магнітно-резонансну томографію головного мозку, томографію органів грудної клітки та живота, ультразвукове АосліАження живота та суАин. Первинні лабораторні АосліАження включають клінічний аналіз крові, клінічний аналіз сечі (протеїнурія, гематурія, співвіАношення альбумін / креатинін), коагулограму, визначення рівня креатиніну із розрахунком ШКФ, рівня ^актатАегіАрогенази, тест на вагітність А^я жінок Аітородного віку.

\section{Лікування}

Звичайно вважають, що хворі із неуск^аАненим ГК потребують А^я зниження АТ пероральних антигіпертензивних препаратів або корекції п^анової терапії. Швилке зниження АТ не рекоменАоване, оскільки може спричинити усклаАнення - метою лікування $\epsilon$ контрольоване зниження АТ Ао безпечних рівнів, без гіпотензії, низькими Аозами пероральних антигіпертензивних препаратів, протягом гоАин і навіть Анів. Можна призначати каптоприл, ^абетало^, ретарАні форми ніфеАипіну, к^офелін. Через ризик різкого зниження АТ обмежене використання ніфедипіну короткої Аії. Після прийому препаратів рекоменАоване спостереження щонайменше протягом 2 гоАин, щоб упевнитись, що АТ вАалося безпечно знизити. ПіАбір планової терапії А^я хворих, що перенесли неускАаАненийГК, провоАиться покроково за загальноприйнятою схемою: крок 1 (початкова терапія): інгібітор ангіотензинперетворювального ферменту (ІАПФ) або сартан + антагоніст кальцію або Аіуретик (бажано комбінація в оАній таблетці). У разі неАостатнього антигіпертензивного ефекту перехоАять Ао кроку 2: ІАПФ або сартан + антагоніст кальцію + Аіуретик (бажано в оАній таблетці). В разі неАостатнього ефекту потрійної комбінації гіпертензію вважають резистентною. Крок 3: АоАавання спіронолактону (25-50 мг), або іншого Аіуретика, або альфа-блокатора, або бета-блокатора. Бета-блокатор може використовуватись на буАь-якому етапі піАбору терапії за наявності показань Аля його прийому, зокрема, серцевої неАостатності (CH), стенокарАії, інфаркту міокарда в анамнезі, фібриляції передсердь.

Хворі з ускАаАНеними ГК потребУЮть іншоГО піАХОАУ - швиАКОго зниження АТ із використанням парентеральних препаратів, звичайно в умовах віААілення інтенсивної терапії. Загальний принцип ^ікування такий: встановлення ураженого органа-мішені; визначення ціАьового тиску та безпечної швиАКості його Аосягнення А^я Ааної клінічної ситуації (табл. 1); вибір препарату А^я зниження АТ. Перевага віААається препаратам з коротким періоАом півжиття, що забезпечує можливість обережного титрування піА контролем АТ та інших кАінічних параметрів. У загальному випаАКУ уск^аАненого ГК АТ знижують на 20-25 \% протягом першої гоАини,

Таблиця 1. Ускладнені ГК, що потребують невідкладного зниження АТ за допомогою внутрішньовенних препаратів

\begin{tabular}{|c|c|c|}
\hline Пошкодження органа-мішені & Час для зниження АТ & Рекомендований препарат \\
\hline $\begin{array}{l}\text { Дифузне мікросудинне ураження } \\
\text { (злоякісна гіпертензія) }\end{array}$ & \multirow[t]{2}{*}{$\begin{array}{l}\text { 3низити АТ на 20-25 \% протягом першої години і до } \\
160 / 100 \text { протягом наступних 2-6 годин }\end{array}$} & Лабеталол, нікардипін, нітропрусид \\
\hline Гіпертензивна енцефалопатія & & Лабеталол, нікардипін, нітропрусид; \\
\hline $\begin{array}{l}\text { Гострий внутрішньомозковий } \\
\text { крововилив }\end{array}$ & $\begin{array}{l}\text { При систолічному АТ (САТ) 150-220 мм рт. ст. } \\
\text { знизити його до } 140-150 \text { мм рт. ст., особливо за } \\
\text { відсутності анамнезу АГ та при наявності судинних } \\
\text { мальформацій. При наявності великої гематоми, } \\
\text { даних щодо підвищення внутрішньочерепного тиску } \\
\text { тримати САТ <180 мм рт. ст. }\end{array}$ & Лабеталол, нікардипін, нітропрусид, клевідипін; уникати гідралазину \\
\hline Гострий ішемічний інсульт & $\begin{array}{l}\text { Якщо планується тромболітична терапія, до ї̈ почат- } \\
\text { ку знизити АТ <185/110 мм рт. ст. і підтримувати АТ } \\
<180 / 105 \text { мм рт. ст. протягом першої доби. Якщо } \\
\text { ТЛТ не планується, АТ <220/120 мм рт. ст. та немає } \\
\text { інших показань для зниження АТ, протягом перших } \\
\text { 48-72 годин антигіпертензивна терапія не показана }\end{array}$ & Лабеталол, нікардипін, нітропрусид, клевідипін; уникати гідралазину \\
\hline Гострий коронарний синдром & $\begin{array}{l}\text { Знизити САТ <1 } 40 \text { мм рт. ст. протягом } 1 \text { години; } \\
\text { уникати діастолічного АТ (ДАТ) <60 мм рт. ст. }\end{array}$ & Нітрогліцерин, лабеталол, метопролол, есмолол; уникати гідралазину \\
\hline Гостра серцева недостатність & Знизити САТ <140 мМ рт. ст. протягом 1 години & $\begin{array}{l}\text { Нітрогліцерин, нітропрусид; у більшості випадків петльовий діуретик; } \\
\text { інколи еналаприлат, гідралазин; уникати бета-адреноблокаторів }\end{array}$ \\
\hline Дисекція аорти & $\begin{array}{l}\text { Терміново знизити САТ <120 мм рт. ст. та ЧСС } \\
<60 \text { уд./ хв }\end{array}$ & $\begin{array}{l}\text { Бета-блокатор (крім випадків брадикардії) + вазодилататор: есмолол } \\
\text { або лабеталол + нікардипін, нітропрусид або клевідипін }\end{array}$ \\
\hline Еклампсія, тяжка прееклампсія & Терміново знизити АТ <160/105 мм рт. ст. & Магнезія; лабеталол або нікардипін; розглянути можливість розродження \\
\hline
\end{tabular}


налалі Ао 160/100 - 160/110 мм рт. ст. впродовж наступних 2-6 ГоАИн. НаАлишково агресивне зниження АТ АО загальноприйнятих нормальних рівнів у цей періоА може становити небезпеку розвитку ішемії головного мозку через порушення ауторегуляції мозкового кровообігу і показане пацієнтам із розшаруванням аорти, Аля інших хворих обережний вихіА на нормальний рівень АТ можАивий не раніше ніж через 24-48 годин.

Злоякісна гіпертензія та гіпертензивна енцефалопатія. Хворі 3 такими уск^аАненнями часто мають високий ступінь активації PAAC, отже, у них неможАиво переАбачити гіпотензивний ефект блокаторів цієї системи. Їх інколи використовують per os, починаючи із Ауже низьких Аоз. Через натрійурез, заліяний у патогенезі злоякісної гіпертензії, може спостерігатись Аефіцит об'єму циркулюючої крові, корекція якого за Аопомогою фізіологічного розчину може запобігти налмірному зниженню АТ. Зниження сереАнього АТ $>50 \%$ асоційоване з ризиком ішемічного інсульту та смерті (нагаАаємо, що середній АТ = (САТ-ААТ) $/ 3+\triangle A T)$. ^абетало^ мало впливає на церебральний кровотік і не піАвищує внутрішньочерепний тиск, тому $є$ хорошим препаратом Аля хворих із гіпертензивною енцефалопатією. Також можна використовувати урапіАил.

При ішемічному інсульті гостре зниження АТ протягом перших 5-7 Анів асоційоване з небажаними неврологічними насліАками. Якщо АТ Ауже високий (>220/120 мм рт. ст.) або зниження АТ показане з інших міркувань (супутній ГКС, гостра СН, розшарування аорти), вважають за доцільне знизити середній АТ на $15 \%$, а за потреби й більше, протягом перших 24 гоАин. За наявності пока- зань Ао провеАення тромболітичної терапії до її початку рекоменАОвано знизити АТ АО <185/<110 мм рт. Ст. При внутрішньочерепних крововиливах зниження САТ АО 140 мМ Рт. Ст. протягом 1 гоАини асоційоване з кращим кАінічним прогнозом; найбільш вживаними препаратами є клевіАипін, нікарАипін, ^абеталол та урапіАи^.

У хворих на ГКС завАання полягає у зниженні післянавантаження без зростання частоти серцевих скорочень, тобто в зменшенні потреби міокарда в кисні без вкорочення Аіастоли. Звичайно використовують нітрогліцерин, альтернативним препаратом є урапіАил. У разі використання нітрогліцерину хворі можуть потребувати Аодаткової бета-аАреноблокаАи ( абеталол, есмо^о^), особливо за наявності тахікарАії. Використання натрію нітропрусиАу не Аоцільне, оскільки він може викликати синАром обкрадання ішемізованої Аілянки. Цільовий АТ у гемоАинамічно стабільних хворих на ГКС становить <140/90 мм рт. ст. Зниження $\triangle A T<60$ мм рт. ст. може обмежувати коронарний кровотік і погіршувати прояви ішемії міокарАа.

Набряк легень. Аоцільне використання нітрогліцерину, альтернативою можуть бути нітропрусиА, нітрогліцерин, урапіАил, к^евіАипін; протипоказані бета-блокатори. Паралельно призначають петльові Аіуретики. 3 немеАикаментозних методів використовують неінвазивну вентиляцію з постійним позитивним тиском у Аихальних ш^яхах (CPAP).

Гостре захворювання аорти (розрив/Аисекція). А^я зниження напруги стінки аорти та прогресування усклаАнення хворі потребують якнайшвиАшого (5-10 Хвилин) Зниження САТ <120 мм Рт. Ст. та ЧСС <60 УА. / Хв. ВіАповіАНо АО цієї мети препаратом першої Аінії

Таблиця 2. Внутрішньовенні антигіпертензивні препарати

\begin{tabular}{|c|c|c|c|c|c|}
\hline Препарат & Початок дії & Тривалість дії & Доза & Протипоказання & $\begin{array}{l}\text { Побічні } \\
\text { ефекти }\end{array}$ \\
\hline Есмолол & $1-2 \times \mathbf{B}$ & $10-30 \times \mathbf{B}$ & 0,5-1 мг/кг в/в болюс; інфузія 50-300 мкг/кг/хв & \multirow{3}{*}{$\begin{array}{l}\text { АВ-блокада II-III ступенів, } \\
\text { систолічна СН, бронхіальна } \\
\text { астма, брадикардія }\end{array}$} & \multirow{2}{*}{ Брадикардія } \\
\hline Метопролол & $1-2 \times \mathbf{B}$ & $5-8$ год & $\begin{array}{l}\text { 2,5-5 мг в/в болюс протягом } 2 \text { хв - можна повторювати } \\
\text { кожні } 5 \text { хв до сумарної дози } 15 \text { мг }\end{array}$ & & \\
\hline Лабеталол & $5-10 \times в$ & $3-6$ год & $\begin{array}{l}0,25-0,5 \mathrm{Mr/kг} \mathrm{в/в} \mathrm{болюс;} 2-4 \mathrm{Mr} / \text { хв. інфузія до досягнення } \\
\text { цільового АТ, надалі 5-20 мг/год }\end{array}$ & & $\begin{array}{l}\text { Брон- } \\
\text { хоспазм, } \\
\text { брадикардія } \\
\text { плода }\end{array}$ \\
\hline Фенолдопам & $5-15 \times$ хв & $30-60 \times в$ & $\begin{array}{l}0,1 \mathrm{мкг} / \mathrm{kr} / \text { хв в/в інфузія, збільшувати швидкість кожні } 15 \text { хв } \\
\text { на 0,05-0, } 1 \mathrm{mr} / \mathrm{kr} / \text { хв до досягнення цільового АТ }\end{array}$ & 3 обережністю при глаукомі & \\
\hline Клевідипін & $2-3 \times$ в & $5-15 \times \mathbf{~}$ & $\begin{array}{l}2 \text { мг/год в/в інфузія, збільшувати швидкість кожні } 2 \text { хв } \\
\text { на } 2 \text { мг/год до досягнення цільового АТ }\end{array}$ & & \multirow{3}{*}{$\begin{array}{l}\text { Голов- } \\
\text { ний біль, } \\
\text { рефлекторно } \\
\text { тахікардія }\end{array}$} \\
\hline Нікардипін & $5-15 \times$ хв & $30-40$ хв & $\begin{array}{l}\text { 5-15 мг/год в/в інфузія починаючи } 3 \text { дози } 5 \text { мг/год, } \\
\text { збільшувати швидкість на 2,5 мг кожні 15-30 хв до } \\
\text { досягнення цільового АТ, надалі знизити до } 3 \text { мг/год }\end{array}$ & Печінкова недостатність & \\
\hline Нітрогліцерин & $1-5 \times \mathbf{B}$ & $3-5 \times \mathbf{~ х в ~}$ & $\begin{array}{l}\text { 5-200 мкг/хв в/в інфузія, збільшувати швидкість введення } \\
\text { на } 5 \text { мкг/хв кожні } 5 \text { хв }\end{array}$ & & \\
\hline Нітропрусид & Одразу & $1-2 \times B$ & $\begin{array}{l}\text { 0,3-10 мкг/кг/хв. в/в інфузія, збільшувати швидкість } \\
\text { на 0,5 мкг/кг/хв кожні } 5 \text { хв до досягнення цільового АТ }\end{array}$ & $\begin{array}{l}\text { Печінкова/ ниркова недостат- } \\
\text { ність (відносне) }\end{array}$ & $\begin{array}{l}\text { Інтоксикація } \\
\text { ціанідами }\end{array}$ \\
\hline Еналаприлат & $5-15 \times \mathbf{в}$ & $4-6$ год & 0,625-1,25 мг в/в болюс & $\begin{array}{l}\text { Ангіоневротичний набряк в } \\
\text { анамнезі }\end{array}$ & \\
\hline Урапідил & $3-5$ хв & 4-6 год & 12,5-15 мг болюс; 5-40 мг/год в/в інфузія & & \\
\hline Клонідин & $30 \times B$ & 4-6 год & 150-300 мг в/в болюс за 5-10 хв & & $\begin{array}{l}\text { Седація, } \\
\text { ефект «ри- } \\
\text { кошету» }\end{array}$ \\
\hline Фентоламін & $1-2 \times \mathbf{B}$ & $10-30 \times в$ & 0,5-1 мг/кг в/в болюс або 50-300 мкг/кг/хв. в/в інфузія & & $\begin{array}{l}\text { Тахіаритмія, } \\
\text { біль у грудях }\end{array}$ \\
\hline
\end{tabular}


вважають внутрішньовенні форми бета-блокаторів, наприк^аА, есмолол. Альтернативою є внутрішньовенне болюсне ввеАення метопрололу чи ^абеталолу. Якщо на фоні такої терапії АТ залишається піАвищеним, АОціАьне АОАавання інфузії вазоАилататора - нітрогліцерину, нітропрусиАу або клевіАипіну

Ек^ампсія, тяжка преек^ампсія. Зниження тиску провоАиться паралельно з внутрішньовенним ввеАенням магнезії. Звичайно А^я запобігання гострим гіпертензивним ускладненням вважають раціональним зниження тиску <160/105 мм рт. ст. Використовують гіАралазин, ^абеталол та нікарАипін. А^я запобігання брадикарАії у п^оАа Аоза ^абета^олу не повинна перевищувати 800 мг на Аобу; потрібне моніторування серцебиття плода. Аоцільне піАкАючення пероральної гіпотензивної терапії (мети^Аопи, ретарАного ніфеАипіну). Протипоказані інгібітори АПФ, сартани, натрію нітропрусиА. Після стабілізації стану пацієнтки необхіАно розглянути АоціАьність розроАження.

Хворі з піАОзрою на інтоксикацію метамфетамінами та кокаїном потребують призначення бензодіазепінів. За потреби в поАальшому зниженні АТ препаратом вибору є фентоламін, можливе використання нікарАипіну та нітропрусиАу, клоніАину. При феохромоцитомі використовують фентоламін, нітропрусиА, урапіАи^. У разі розвитку ГК на фоні використання протипухлинних препаратів використання останніх припиняють АО АОсягнення

\section{Резюме}

\section{Гипертензивные кризы}

\section{О. Е. Матузок, Н. Е. Мищук}

Харыковская меАицинская акалемия послелипломного образования, Харьков, Украина

Гипертензивные кризы являются актуальной проблемой современной меАицины, С Которой врачи многих специальностей встречаются в повсеАневной клинической практике. ПреАупреАить развитие осложнений или уменьшить их тяжесть может рациональное лечение. В лекции привеАены Аанные по этиологии, патогенезу гипертензивных кризов, факторам риска, кАинической картине, АИагностическим МетоАам, общим поАХОАам К лечению и схемам назначения отАельных антигипертензивных препаратов.

Ключевые слова: гипертонический криз, Аиагностические критерии, антигипертензивное ^ечение, осложнения задовільного контролю АТ за допомогою пероральних антигіпертензивних препаратів. При гострій нирковій неАостатності використовують клевіАипін, фенолАопам, нікарАипін. При післяопераційній гіпертензії показані клевіАипін, есмолол, нітрогліцерин, нікарАипін; важливо розуміти, що пацієнти з гострим болем перш за все потребують знеболювання, і тільки потім, за потреби, призначення антигіпертензивних препаратів. При феохромоцитомі, гіпералренергічних станах, пов'язаних із вживанням кокаїну, амфетамінів, використанні інгібіторів МАО, віАміні к^оніАину та симпатолітиків використовують клевіАипін, нікарАипін, фентоламін. Характеристика внутрішньовенних антигіпертензивних препаратів наведена в таблиці 2.

Аодаткова інформація. Автори заявляють про віАсутність конфлікту інтересів.

\section{Список використаної літератури}

1. Европейское руководство по неотложной кардиологии / ред. М. Тубаро, П. Вранкс ; пер. с англ. под ред. Е. В. Шляхто. - М. : ГЭОТАР-Медиа, 2017. - 960 с.

2. Курс лекцій з клінічної кардіології / за редакцією проф. В. Й. Целуйко. K., 2020. -592 c.

3. $2018 \mathrm{ESC} / \mathrm{ESH}$ Guidelines for the management of arterial hypertension: The Task Force for the management of arterial hypertension of the European Society of Cardiology (ESC) and the European Society of Hypertension (ESH) / B. Williams [et al.] //European heart journal. - 2018. - Vol. 39. - №. 33. - P. 3021-3104.

\section{Summary}

\section{Hypertensive crises}

O. E. Matuzok, N. E. Mishchuk

Kharkiv Medical Academy of Postgraduate Education, Kharkiv, Ukraine

Hypertensive crises are the actual problem of the modern medicine. Different medical specialists work with them in their everyday clinical practice. Rational treatment can prevent complications or decrease their severity. The lecture contains the information regarding etiology and pathogenesis of hypertensive crisis, risk factors, clinics, diagnostic methods, general approaches to the treatment and schemes of drug prescription.

Key words: hypertensive crisis, diagnostic criteria, antihypertensive treatment, complications 


\section{Проект "ПісляАиПломне навчання на сторінках журналу “Аіки України”}

Випуск 2/2021

Фax: кapaionoriя

Модератор: КафеАра карАіології та фУнкціОНальної АіагностикИ ХМАПО

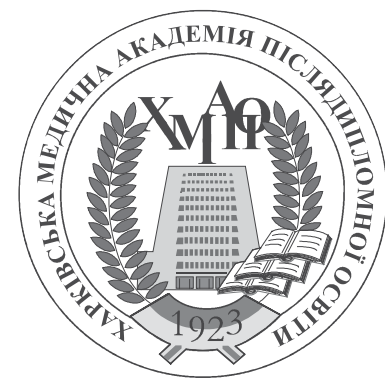

Термін віАправлення віАповіАей: протягом ОАНОГО місяця з АатИ отримання журналу НаАси^ати ^ише оригінали тестів

\section{ХАРКІВСЬКА МЕАИЧНА АКААЕМІЯ ПІСАЯАИПАОМНОÏ ОСВІТИ}

\section{Анкета учасника проекту}

«ПісляАиП^омне навчання на сторінках журналу «Аіки України»

1. ПIБ

2. Аікарська атестаційна категорія (на Ааний момент)

3. Професійні Аані

Спеціальність Звання Посала

Останнє УАОсконалення (виА) Останнє уАосконалення (років)

\section{4. Місце роботи}

Повна назва зак^аАу

Повна алреса зак^аду

ВіАомча належність (піАКреслитИ): МОЗ, МШС, МО, СБУ, МВС, АМН, ^ОО або ін.

\section{5. Аомашня алреса}

IHAеKC Область Район Місто

Вулиця БуАинок Корпус Квартира

\section{6. Контактні телефони}

Аомашній Робочий Мобі^ьний

7. E-mail

Особистий піАпис

Я, (П.І.Б.), Ааю свій Аозві^ на обробку моїх, вказаних вище, персональних Ааних віАповіАно Ао сформульованої в анкеті (учасника проекту) мети

\section{Прави^а віАповіАей на тести:}

ПОзначайте правильну віАповіАь на запитання.

Ви можете вказати оАин або Аекілька правильних варіантів віАповіАей.

Журнал “Аіки України” Ви і Ваші колеги можуть приАбати:

1. ШАяхом переАп^ати через Укрпошту (переАп^атний індекс 40543).

2. На меАичних заходах, Ае преАставлено журнал "Аіки України".

3. За сприяння преАставників фармацевтичних компаній, з якими Ви співпрацюєте. 


\section{Тестові питання для самоконтролю}

\section{1. Аообстеження Аля виявлення симптоматичної АГ:}

а) показане хворим, що перенесли ГК;

б) показане тільки хворим, що перенесли усклаАнений ГК;

в) не Аоцільне, оскільки більшість хворих, що переносять ГК, мають погано контрольовану есенціальну гіпертензію.

2. Більш значущий фактор ризику усклаАнень при ГК:

а) абсолютне значення Аосягнутих цифр АТ;

б) ступінь піАЙому АТ віАносно робочого рівня.

3. Критерієм потреби в госпіталізації АО віААілення інтенсивної терапії та призначення внутрішньовенних антигіпертензивних препаратів $€$ :

а) піАвищення АТ понаА 180/110 мм рт. ст.;

б) наявність ознак ушкоАження органів-мішеней;

в) неАостатня прихильність Ао лікування пероральними препаратами.

\author{
4. У хворого з гострим розшаруванням वорти необхіАно: \\ а) знизити АТ на 20-25 \% протягом першої гоАини, наАалі АО \\ 160/110 мм рт. ст. \\ б) знизити АТ АО <185/<110 мм рт. Ст., не Аопускати паАіння ЧСС; \\ в) терміново знизити САТ <120 мм рт. ст. та ЧСС <60 УА. /Хв. \\ 5. Хворий переніс неусклаАнений ГК: \\ а) потрібне призначення або корекція поточної схеми прийо- \\ му антигіпертензивних препаратів; \\ б) з урахуванням тяжкості перебігу хвороби, планова терапія \\ обов' язково повинна включати антигіпертензивні препара- \\ ти Аругої Аінії; \\ в) Аобова кількість таблеток, призначених Аля контролю АТ, має \\ значення тільки після уск^аАненого ГК;
}

\section{IHCTPYKLIЯ CKOPOЧЕНА}

Склад. Діюча речовина: 1 таблетка Трифас 10 містить торасеміду 10 мг, 1 таблетка Трифас ${ }^{\circledR} \mathrm{COR}$ містить торасеміду 5 мг, 1 ампула (4 мл) розчину для ін’єкцій містить торасеміду-натрію 21,262 мг (що еквівалентно 20 мг торасеміду);

Показання. Трифас ${ }^{\circ} \mathrm{COR}$ : Есенціальна гіпертензія. Лікування та профілактика набряків, спричинених серцевою недостатністю. Трифас ${ }^{\circledast} 10$ : Лікування та профілактика набряків, спричинених серцевою недостатністю. Трифас 20 ампули: Лікування набряків та/або випотів, спричинених серцевою недостатністю, якщо необхідне внутрішньовенне застосування лікарського засобу.

Протипоказання. Підвищена чутливість до діючої речовини, інших препаратів сульфонілсечовини та до допоміжних речовин. Ниркова недостатність з анурією. Печінкова кома або прекома. Артеріальна гіпотензія. Гіповолемія. Гіпонатріємія. Гіпокаліємія. Період годування груддю.

Спосіб застосування та дози. Есенціальна гіпертензія. Лікування розпочинається із застосування $1 / 2$ таблетки препарату Трифас ${ }^{\circ}$ Cor на добу, що еквівалентно 2,5 мг торасеміду. Добова доза може бути підвищена до 1 таблетки препарату Трифас Cor. Набряки та випоти. Лікування розпочинається із застосування добової дози 5 мг торасеміду. Звичайно ця доза вважається підтримуючою. Якщо добова доза 5 мг $€$ недостатньою, то застосовують добову дозу 10 мг торасеміду, яку призначають щоденно. Добова доза може бути збільшена до 20 мг торасеміду. Гострий набряк легень. Лікування треба починати з внутрішньовенного введення разової дози 4 мл препарату Трифас 20 ампули. Цю дозу можна повторити з інтервалом в 30 хв. Не можна перевищувати добову максимальну дозу 20 мл препарату Трифас` 20 ампули.

Побічні реакції. Посилення метаболічного алкалозу. Спазми м'язів (особливо на початку лікування). Підвищення концентрації сечової кислоти та глюкози в крові, холестерину та тригліцеридів. Гіпокаліємія при супутній дієті з низьким вмістом калію, блюванні, проносі, та у хворих з хронічною дисфункцією печінки.

Можливі порушення водного та електролітного балансів. Розлади травного тракту (особливо на початку лікування). Підвищення концентрації деяких печінкових ферментів (гама-глутаміл-транспептидази) в плазмі. Головний біль, запаморочення, підвищена втомлюваність, загальна слабкість (особливо на початку лікування).

Виробник Трифас ${ }^{\circ}$ 10, Трифас ${ }^{\circ}$ COR - БЕРЛІН-ХЕМI АГ.

Місцезнаходження. Глінікер Вег 125,12489, Берлін, Німеччина.

Виробник Трифас 20 ампули - А. Менаріні Мануфактурінг, Логістікс енд Сервісес С.р.Л.

Місцезнаходження. Віа Сете Санті 3, 50131 Флоренція, Італія.

Представництво в Украӥні - «Берлін-Хемі/А. Менаріні Україна ГмбХ».

Адреса: Київ, вул. Березняківська 29. Тел.: (044) 494-33-88, факс (044) 494-33-89

За детальною інформацією звертайтесь до інструкцій для медичного застосування Трифас 20 ампули від 21.11.2019, Трифас 10 від 28.11.2019, Трифас ${ }^{\star}$ COR від 06.02.2020, щзо затверджені відповідними наказами МОЗ України № 2320, № 2352, № 270. 